\title{
Prospect and Challenges of Basic Chemicals Industries in Bangladesh
}

\author{
Md. Sultan Salahuddin* \\ DGM (Plant Operation), ASM Chemical Industries Ltd.
}

\section{Introduction}

Basic Chemicals Industries in Bangladesh belong to mainly Chlor-Alkali Plant \& its Chlorinated product and Hydrogen peroxide plant. Main products are being produced from these basic chemicals Industries are Caustic Soda $(\mathrm{NaOH})$, Chlorine (Cl2), Hydrochloric Acid $(\mathrm{HCl})$, Sodium Hypochlorite ( $\mathrm{NaOCl}$ ), Stable Bleaching Power (SBP), Chlorinated Paraffin Wax (CPW) and Hydrogen Peroxide (H2O2).

The Basic chemicals products of interest are now being supplied through import and local production. We can name only four /five companies who produce basic chemicals locally.ASM Chemical Industries Ltd., Global Heavy Chemicals Ltd, Samuda Chemical Complex ltd., Tasnim Chemical Complex and HP Chemicals are very important names who took challenges in this sector.

\section{Justification for setting up the basic chemicals project}

Chemical sector of our country was too much import dependent. Traders were predominant in the market. In last three decades trading surplus has accumulated and now the time has come to transfer the fund to capital market. Market competition is getting sharper and sharper everyday. It is very high time to thing about value addition. Our industrial development was too much garments oriented and this is time for product diversification. Garments sector is now dependent on import for chemicals. As the market has already developed in the country we should set up chemical plants in the country.

Basic chemical manufacturing capability is a parameter of understanding development level of a country. These things make a country independent of multinational pressure survival of our pharmaceutical industry; our textile industry, Dyeing Industry, leather industry and water treatment and Waste water treatment etc. are dependent on basic chemicals. The Chlor-Alkali Plant is one step towards production of PVC in our country. We don't have Iron ore, Aluminium ore etc. We are heavily dependent on trees for our daily life. Chlor-Alkali Plant will make way to set up PVC Plant for environment protection.

\section{Market demand}

Outputs of Chlor-Alkali and $\mathrm{H} 2 \mathrm{O} 2$ plant are basic chemicals and basic chemicals are necessary for almost all industries. The products that are produced from ChlorAlkali and $\mathrm{H} 2 \mathrm{O} 2$ plant have very good demand in our textile industries, Dyeing Industries, edible oil industries, cable industries, pharmaceuticals, PVC industries, steel rerolling mills, leather industries, WTP and ETP plant etc.

\section{Methodology of basic chemicals demand analysis}

We studied import data of Bangladesh that had been collected from NBR. Also we gathered information from different government, semi-government and private organizations. After collecting those data we compiled them to ascertain aggregate market demand and their growth trend. The figures looked attractive.

\section{CAUSTIC SODA}

One of the main basic chemical is caustic soda. Its chemical name is Sodium Hydroxide $(\mathrm{NaOH})$. It is an industrial product. Different industries use Caustic Soda as raw material. We name here few of the large consuming industries of Caustic Soda consumption such as Soap, glass, drugs, paper \& pulp, textile, leather, sugar, WTP and ETP etc.

\section{IMPORT OF CAUSTIC SODA}

After analyzing following historical data of import it was found that the growth rate in last 8 years was $5 \%$. We have calculated projected demand of caustic soda for next 7 years with same growth rate and we think it is logical. We have only four caustic soda manufacturing project in our country that can meet a small portion of our demand.

\section{HYDROGEN PEROXIDE}

Our main basic chemical is Hydrogen Peroxide $\left(\mathrm{H}_{2} \mathrm{O}_{2}\right)$. Market size in our country is ever bigger like caustic soda. Textile, Dyeing, medicine, pharmaceuticals, cleaning agent, pulp and paper etc Industries use Hydrogen Peroxide in huge quantity. Hydrogen Peroxide is also imported in our country from China, Korea, and Thailand.

\section{IMPORT OF HYDROGEN PEROXIDE}

There is only three Hydrogen Peroxide Plants in our country. Two plants produce $50 \%$ concentration $\mathrm{H} 2 \mathrm{O} 2$ and one plant produces $35 \%$ concentration Hydrogen Peroxide. Major market consumes $50 \%$ concentration. Some quantity of $50 \%$ concentration $\mathrm{H}_{2} \mathrm{O}_{2}$ is imported from China, Korea and Thailand.

\section{HYDROCHLORIC ACID}

In the process of producing Caustic Soda we get Hydrogen $(\mathrm{H} 2)$ and Chlorine $(\mathrm{Cl} 2)$ as bi product. We will make very good use of $\mathrm{H} 2$ and $\mathrm{Cl} 2$ to produce different bi products. One bi product that we have decided to produce is Hydrochloric acid. It is used in metal industry, effluent treatment plant, pharmaceutical industries, leather industries and many other industries. 
It can be produced two categories of $\mathrm{HCl}$, one is high quality with concentration $32 \sim 33 \%$ concentration by ion exchange membrane process and another is low grade is bi product from CPW process with concentration $28 \sim 30 \%$. High quality $\mathrm{HCl}$ is used in food grade industries, textile mills, resin regeneration in DM plant and pharmaceutical industries. Market demand of hydrochloric acid for last 8 years and its projected demand for next 5 years are shown below with graphical representation.

Table - 1 : Market Demand and Comparative Study of Different Basic Chemical Industries.

\begin{tabular}{|c|c|c|c|c|c|c|c|}
\hline Product name & $\begin{array}{c}\text { ASM } \\
\text { Production } \\
\text { capacity } \\
\text { (MT/Day) }\end{array}$ & $\begin{array}{c}\text { Global } \\
\text { (MT/Day) }\end{array}$ & $\begin{array}{l}\text { Samuda } \\
\text { (MT/Day) }\end{array}$ & $\begin{array}{c}\text { Tasnim } \\
\text { Chemical } \\
\text { (Meghna } \\
\text { Gr.) } \\
\text { (MT/Day) }\end{array}$ & $\begin{array}{c}\text { HP } \\
\text { Chemicals } \\
\text { (MT/Day) }\end{array}$ & $\begin{array}{c}\text { Total } \\
\text { Productio } \\
n \\
\text { Capacity } \\
\text { (MT/day) }\end{array}$ & $\begin{array}{c}\text { Present } \\
\text { Market } \\
\text { demand } \\
\text { (MT/Day) }\end{array}$ \\
\hline $\begin{array}{l}\text { Caustic Soda (100\% } \\
\text { basis Flake/Liquid) }\end{array}$ & $\begin{array}{c}60 \\
\text { (Expandable } \\
\text { to 100) }\end{array}$ & 70 & 60 & 100 & - & 290 & $250 \sim 300$ \\
\hline $\begin{array}{l}\text { Chlorine }\left(\mathrm{Cl}_{2}\right) \\
\text { From Electrolizer }\end{array}$ & 53 & 62 & 53 & 89 & - & 257 & $\begin{array}{c}\mathrm{Cl}_{2} \text { Converted to Liq. } \\
\mathrm{Cl}_{2}, \mathrm{HCl}, \mathrm{SBP}, \mathrm{CPW}, \\
\mathrm{NaOCl} \text { etc. }\end{array}$ \\
\hline $\begin{array}{l}\text { Hydrogen Peroxide } \\
\left(50 \% \text { Conc, } \mathrm{H}_{2} \mathrm{O}_{2}\right)\end{array}$ & 60 & - & 70 & 60 & 28 & 218 & $200 \sim 250$ \\
\hline Chlorine $\left(\mathrm{Cl}_{2}\right)$ liquid & 10 & 10 & 7 & 15 & - & 42 & $10-12$ \\
\hline $\begin{array}{c}\text { Hydrochloric } \\
\text { Acid }(32 \% \mathrm{HCl})\end{array}$ & $110 \times 2$ & $100 \times 2$ & 100 & $140 \times 2$ & - & 800 & $150-170$ \\
\hline $\begin{array}{c}\text { Sodium Hypochlorite } \\
(\mathrm{NaOCl})\end{array}$ & 10 & 10 & 20 & 15 & - & 55 & $10-15$ \\
\hline $\begin{array}{c}\text { Stable Bleaching } \\
\text { Powder (SBP) }\end{array}$ & 20 & 15 & 16 & - & - & 51 & $15-20$ \\
\hline $\begin{array}{l}\text { Chlorinated Paraffin } \\
\text { Wax (CPW) }\end{array}$ & 20 & 10 & 20 & 15 & - & 65 & $15-20$ \\
\hline
\end{tabular}

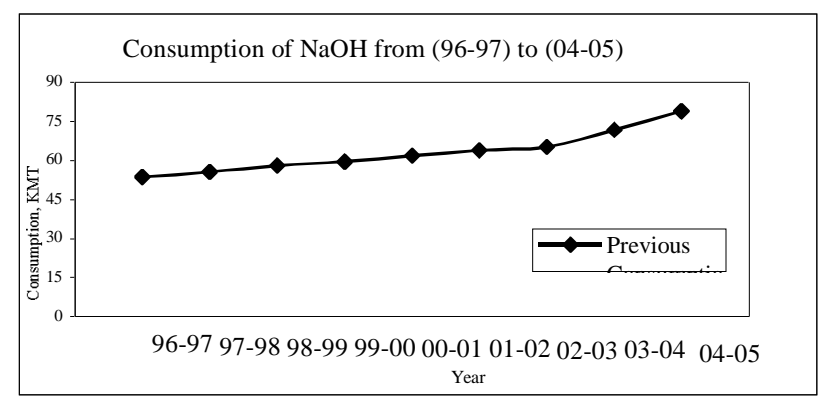

Figure - 1 : Consumption of $\mathrm{NaOH}$ for year (96-97) to (04-05)

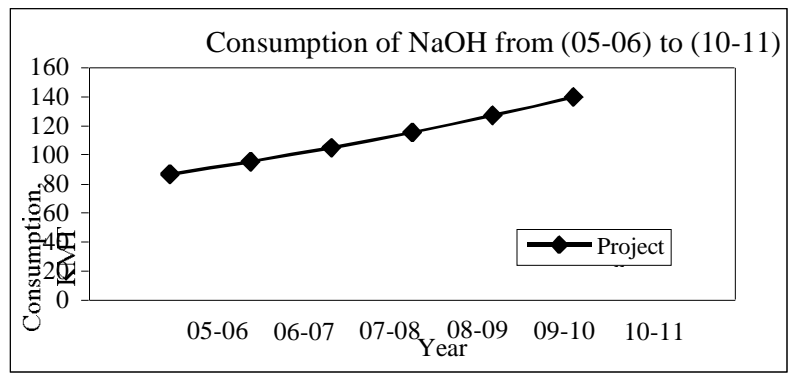

Table - 2 : Consumption of $\mathrm{NaOH}$ and future market demand

\begin{tabular}{|c|c|}
\hline Year & Quantity \\
\hline & MT \\
\hline \multicolumn{2}{|c|}{ Previous Consumption } \\
\hline $96-97$ & 53,510 \\
\hline $97-98$ & 55,538 \\
\hline $98-99$ & 57,910 \\
\hline $99-00$ & 59,440 \\
\hline $00-01$ & 61,690 \\
\hline 01-02 & 63,830 \\
\hline $02-03$ & 65,145 \\
\hline 03-04 & 71,660 \\
\hline $04-05$ & 78,825 \\
\hline \multicolumn{2}{|c|}{ Projected Demand } \\
\hline $05-06$ & 86,708 \\
\hline 06-07 & 95,379 \\
\hline $07-08$ & $1,04,917$ \\
\hline 08-09 & $1,15,408$ \\
\hline $09-10$ & $1,26,949$ \\
\hline $10-11$ & $1,39,644$ \\
\hline
\end{tabular}

Figure - 2 : Projected Demand of $\mathrm{NaOH}$ for year (05-06) to (10-11) 
Table - 3 : Consumption of $\mathrm{H2O} 2$ and future market demand.

\begin{tabular}{|c|c|}
\hline Year & Quantity \\
\hline & MT \\
\hline \multicolumn{2}{|c|}{ Previous Consumption } \\
\hline $96-97$ & 76,551 \\
\hline $97-98$ & 79,613 \\
\hline $98-99$ & 82,798 \\
\hline $99-00$ & 86,109 \\
\hline $00-01$ & 89,554 \\
\hline $01-02$ & 93,136 \\
\hline $02-03$ & 96,861 \\
\hline $03-04$ & 100,736 \\
\hline $04-05$ & 104,765 \\
\hline \multicolumn{2}{|c|}{ Projected Demand } \\
\hline $05-06$ & 108,956 \\
\hline $06-07$ & 113,314 \\
\hline $07-08$ & 117,847 \\
\hline 08-09 & 122,561 \\
\hline $09-10$ & 127,463 \\
\hline $10-11$ & 132,562 \\
\hline
\end{tabular}

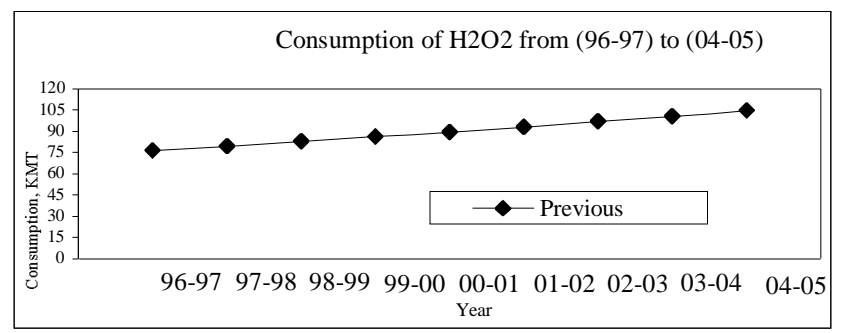

Figure - 3 : Consumption of $\mathrm{H} 2 \mathrm{O} 2$ for year (96-97) to (04-05)

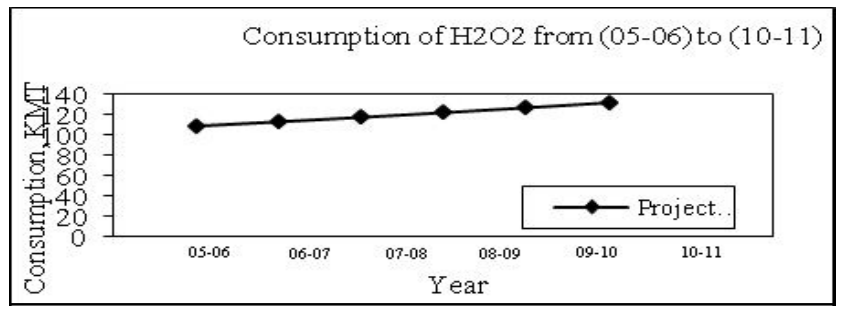

Figure - 4 : Projected Demand of $\mathrm{H}_{2} \mathrm{O}_{2}$ for year (05-06) to (10-11)

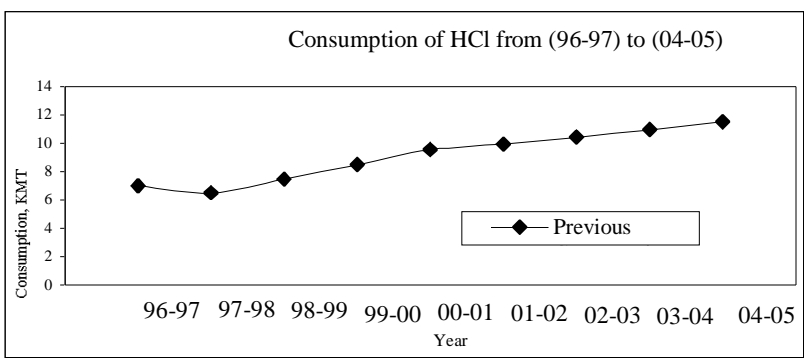

Figure - 5 : Consumption of HCl for year (96-97) to (04-05)
Table -4 : consumption of $\mathrm{HCl}$ and future market demand

\begin{tabular}{|c|c|}
\hline Year & Quantity \\
\hline & MT \\
\hline \multicolumn{2}{|c|}{ Previous Consumption } \\
\hline $96-97$ & 7,000 \\
\hline $97-98$ & 6,508 \\
\hline 98-99 & 7,456 \\
\hline $99-00$ & 8,500 \\
\hline $00-01$ & 9,544 \\
\hline 01-02 & 9.933 \\
\hline $02-03$ & 10,430 \\
\hline 03-04 & 10,951 \\
\hline 04-05 & 11,499 \\
\hline \multicolumn{2}{|c|}{ Projected Demand } \\
\hline $05-06$ & 12,074 \\
\hline 06-07 & 12,677 \\
\hline $07-08$ & 13,311 \\
\hline 08-09 & 13,977 \\
\hline $09-10$ & 14,676 \\
\hline
\end{tabular}

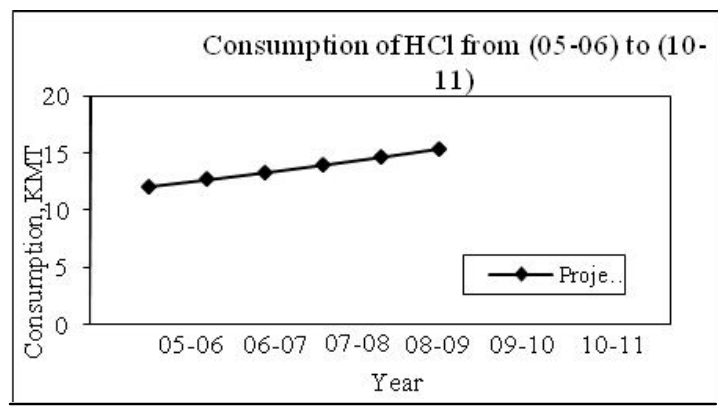

Figure - 6 : Projected Demand of HCl for year (05-06) to (0910)

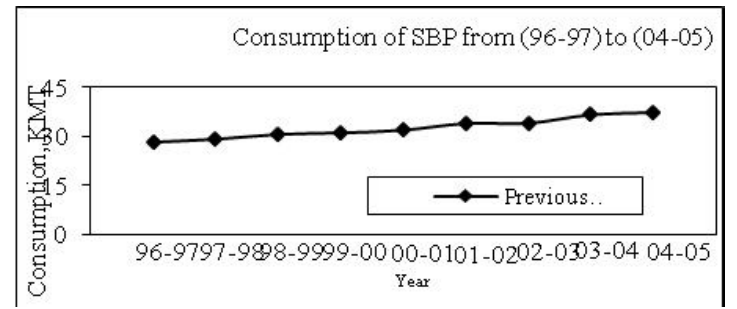

Figure - 7 : Consumption of SBP for year (96-97) to (04-05)

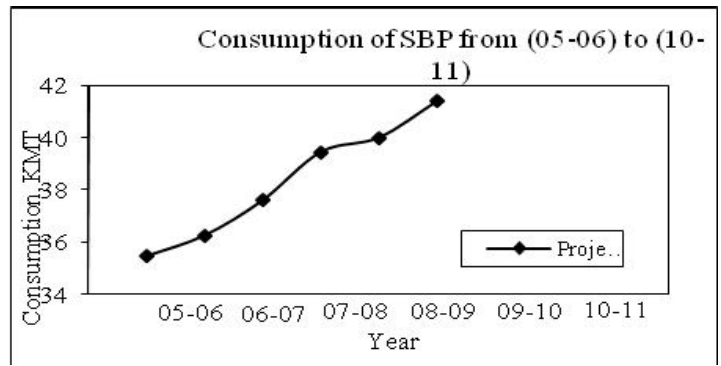

Figure - 8 : Projected Demand of SBP for year (05-06) to $(10-11)$ 
Table - 5 : consumption of SBP and future market demand

\begin{tabular}{|c|c|}
\hline Year & Quantity \\
\hline & MT \\
\hline \multicolumn{2}{|c|}{ Previous Consumption } \\
\hline $96-97$ & 28,050 \\
\hline $97-98$ & 29,000 \\
\hline $98-99$ & 30,550 \\
\hline 99-00 & 31,000 \\
\hline $00-01$ & 31,850 \\
\hline 01-02 & 34,000 \\
\hline $02-03$ & 34,069 \\
\hline $03-04$ & 36,709 \\
\hline $04-05$ & 37,443 \\
\hline \multicolumn{2}{|c|}{ Projected Demand } \\
\hline $05-06$ & 35,450 \\
\hline $06-07$ & 36,250 \\
\hline $07-08$ & 37,600 \\
\hline 08-09 & 39,450 \\
\hline $09-10$ & 40,000 \\
\hline $10-11$ & 41,400 \\
\hline
\end{tabular}

\section{Stable Bleaching Powder (SBP)}

It is a very useful chemical. Not only industrial customers' even domestic customers use this chemical. It is used in textile industry, pulp and paper industries and washing plant. Hospitals, WASA etc. organization use stable bleaching powder in bulk quantity. It has domestic use for cleaning houses, toilets and other places. Market consumption curve and projected demand of Stable Bleaching Powder along with graphical representation are given below.

\section{Chlorinated Paraffin Wax (CPW)}

This product is used to produce inflammable plastic. Plastic product does not produce flame rather it melts. This product is used in PVC industries and in cable factories. Fire from electric short circuit is very common in our country. Production of electric cable with CPW will help to reduce the risk of electric short circuit.

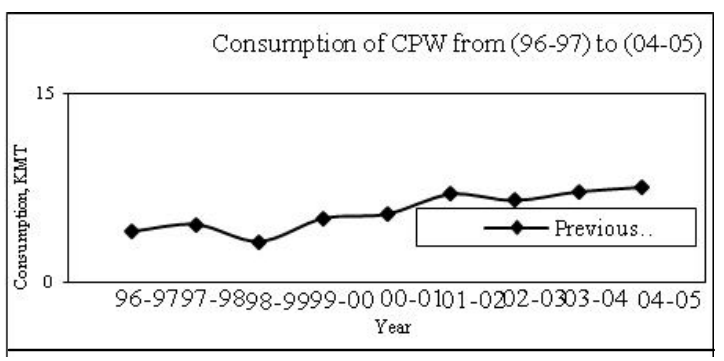

Figure - 9 : Consumption of CPW for year (96-97) to (04-05)
Table - 6 : Consumption of CPW and future market demand

\begin{tabular}{|c|c|}
\hline Year & Quantity \\
\hline & MT \\
\hline \multicolumn{2}{|c|}{ Previous Consumption } \\
\hline $96-97$ & 4,000 \\
\hline $97-98$ & 4,565 \\
\hline $98-99$ & 3,200 \\
\hline 99-00 & 5,050 \\
\hline $00-01$ & 5,400 \\
\hline$\overline{01-02}$ & 7,000 \\
\hline $02-03$ & 6,500 \\
\hline 03-04 & 7,200 \\
\hline 04-05 & 7,560 \\
\hline \multicolumn{2}{|c|}{ Projected Demand } \\
\hline $05-06$ & 7,938 \\
\hline $06-07$ & 8,335 \\
\hline $07-08$ & 8,752 \\
\hline 08-09 & 9,189 \\
\hline $09-10$ & 9,649 \\
\hline $10-11$ & 10,131 \\
\hline
\end{tabular}

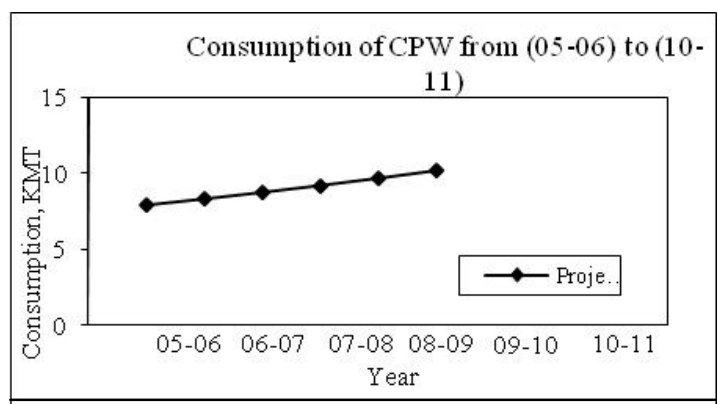

Figure - 10 : Projected Demand of CPW for year (05-06) to (10-11)

\section{USES OF SODIUM HYPOCHLORITE (NAOCL)}

1. Common uses

b. Bleaching-Oxidation

c. Disinfection

d. Odor control

e. Chlorination of drinking water

f. Elimination of slime and algae in swimming pool and boiler water

g. $\mathrm{P}^{\mathrm{H}}$ adjustment

2. Industrial uses

a. It is widely used in soap manufacturing industries,fish processing plants and water treatment projects.

b. Petroleum refineries, oil refineries, food processing industries. Household, Hotels/Motels/Hospitals waste $\&$ sewage treatment, dairies and poultries. 
Table - 7 : Consumption of $\mathrm{NaOCl}$ and future market demand

\begin{tabular}{|c|c|}
\hline Year & Quantity \\
\hline \multicolumn{2}{|c|}{ Previous Consumption } \\
\hline $99-00$ & 850 \\
\hline $00-01$ & 958 \\
\hline $01-02$ & 835 \\
\hline $02-03$ & 778 \\
\hline $03-04$ & 992 \\
\hline $04-05$ & 1305 \\
\hline \multicolumn{2}{|c|}{ Projected Demand } \\
\hline $05-06$ & 1570 \\
\hline $06-07$ & 1665 \\
\hline $07-08$ & 1738 \\
\hline $08-09$ & 1823 \\
\hline $09-10$ & 1908 \\
\hline $10-11$ & 2100 \\
\hline
\end{tabular}

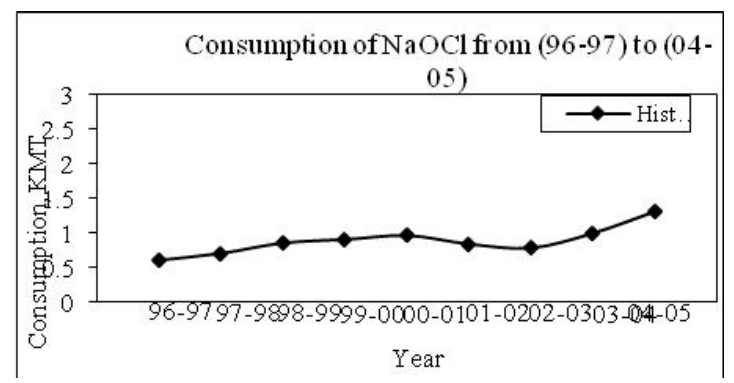

Figure - 11 : Consumption of $\mathrm{NaOCl}$ for year (96-97) to (04-05)

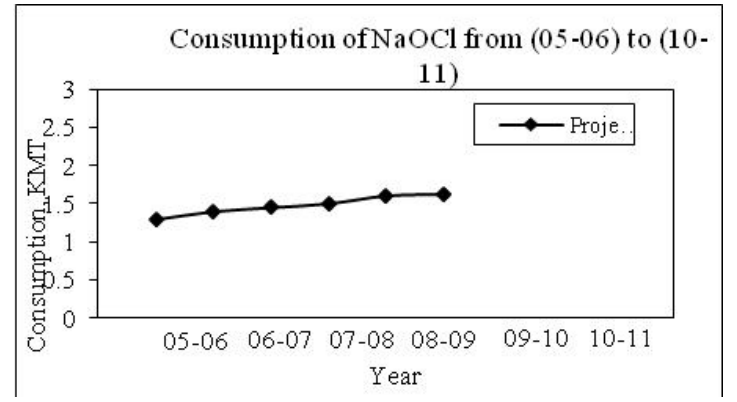

Figure - 12 : Projected Demand of NaOCl for year (05-06) to (1011)

\section{CHLORINE}

It is a bi product of our industry. Everybody is aware that it is a very dangerous gas. Among all developed countries of the world and Middle East produce this gas with utmost care \& affection because PVC production needs Chlorine as raw material. For a viable size of PVC manufacturing plant we need about 400MT of Chlorine everyday. It is already known that the industry like ASM will produce about 53MT of Chlorine everyday. With another 4-5 industries of this size we can have 250MT of Chlorine and our country can set up a PVC industry. Once PVC industry is installed there will be no marketing or demand problem in our country for any Chlor-Alkali project. Our country badly needs PVC industry for the protection of forest resource.

\section{Uses of Chlorine $\left(\mathrm{Cl}_{2}\right)$}

1. Chlorine is used in water treatment and sewage treatment. Chlorine purified water hailed as one of life's top achievement of the millennium. Along with the discovery of gravity, printing and landing of the moon, the use of chlorine-purified water was recently name as one of the millennium's greatest historical events.

2. Chlorine is used to produce Calcium hypo, Sodium hypo, $\mathrm{PVC}, \mathrm{HCl}$ acid, Ammonium Chloride, Calcium Chloride, Zinc Chloride, CPW, Stable bleaching Powder (SBP) etc.

3. It is used in Fertilizer projects, paper mills and other health departments and naval departments for swimming pool.

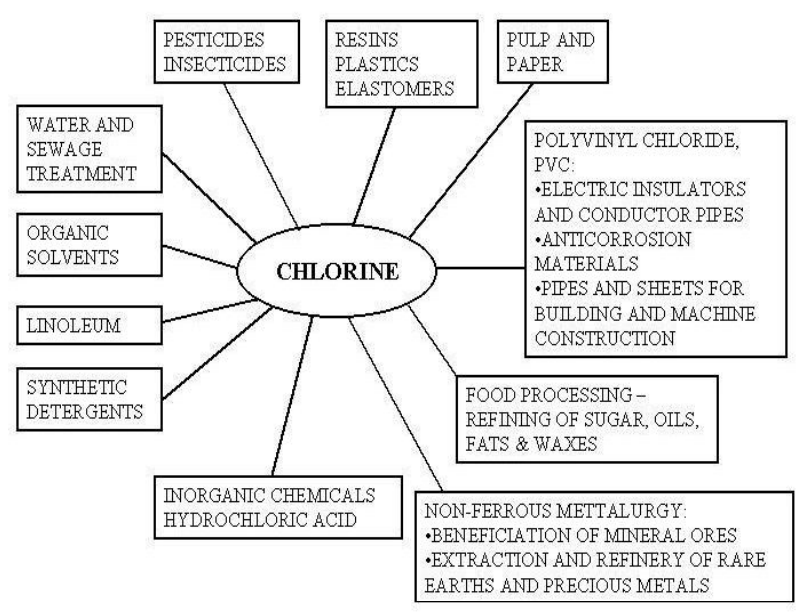

Figure - 13 : Usage of $\mathbf{C l}_{2}$.

Table -8 : Consumption of $\mathrm{Cl}_{2}$ and future market demand

\begin{tabular}{|c|c|}
\hline Year & Quantity \\
\hline & MT \\
\hline \multicolumn{2}{|c|}{ Previous Consumption } \\
\hline 96-97 & 1,800 \\
\hline $97-98$ & 2,000 \\
\hline $98-99$ & 2,200 \\
\hline 99-00 & 1,900 \\
\hline $00-01$ & 1,900 \\
\hline 01-02 & 2,560 \\
\hline $02-03$ & 3,000 \\
\hline 03-04 & 3,506 \\
\hline $04-05$ & 4,010 \\
\hline \multicolumn{2}{|c|}{ Projected Demand } \\
\hline $05-06$ & 4,130 \\
\hline $06-07$ & 4,254 \\
\hline 07-08 & 4,382 \\
\hline 08-09 & 4,513 \\
\hline $09-10$ & 4,649 \\
\hline $10-11$ & 4,788 \\
\hline
\end{tabular}




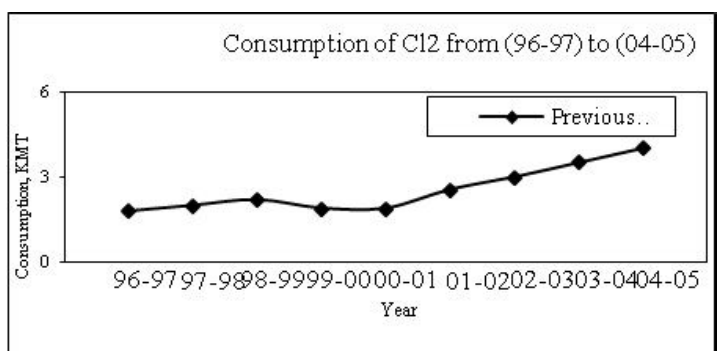

Figure - 13 : Consumption of $\mathrm{Cl}_{2}$ for year (96-97) to (04-05)

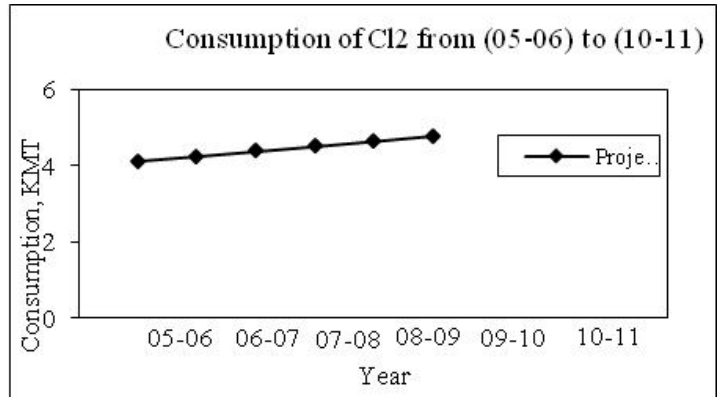

Figure - 14 : Projected Demand of Cl2 for year (05-06) to (10-11)

\section{Uses of activated bleaching earth (ABE)}

Activated Bleaching Earth can be used for the purpose of dcolourant or dry and dehydrogenation against gas or liquid for different kinds of Mineral oil, Edible seed oil, Animal Fat, Solid Wax, Fat Acid, Ethanol and Benzene etc. It is also used for adsorbents of radioactive compounds, binding of oil on water. It can also be used for finishing of wines D Juices and stabilization of beer, clarifying of saccharine syrup.

Table - 8 : consumption of $\mathrm{ABE}$ and future market demand

\begin{tabular}{|c|c|}
\hline Year & Quantity \\
\hline & MT \\
\hline \multicolumn{2}{|c|}{ Previous Consumption } \\
\hline 96-97 & 20,965 \\
\hline $97-98$ & 18,596 \\
\hline $98-99$ & 21,560 \\
\hline $99-00$ & 24,035 \\
\hline $00-01$ & 21,040 \\
\hline $01-02$ & 22,319 \\
\hline $02-03$ & 24,068 \\
\hline 03-04 & 26,000 \\
\hline $04-05$ & 27,300 \\
\hline \multicolumn{2}{|c|}{ Projected Demand } \\
\hline $05-06$ & 28,665 \\
\hline $06-07$ & 30,098 \\
\hline $07-08$ & 31,603 \\
\hline 08-09 & 33,183 \\
\hline $09-10$ & 34,842 \\
\hline $10-11$ & 36,585 \\
\hline
\end{tabular}

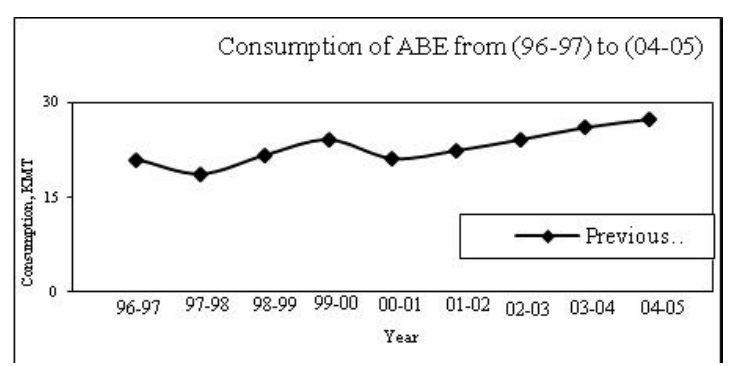

Figure - 15 : Consumption of ABE for year (96-97) to (04-05)

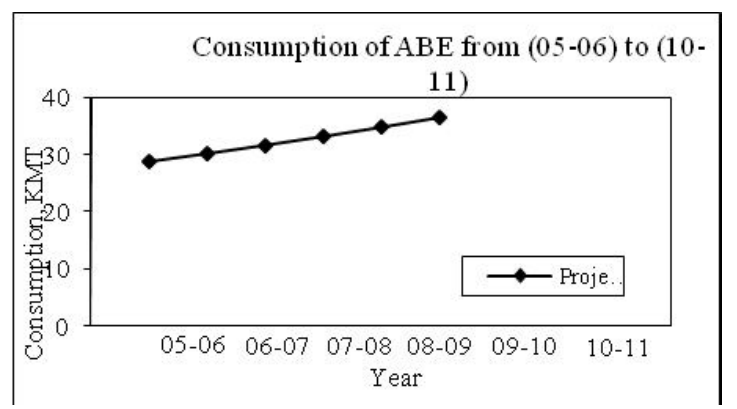

Figure - 16 : Projected Demand of ABE for year (05-06) to (10-11)

\section{Market segmentation and market strategy}

Basic Chemicals products will be generic in nature. In terms of marketing it will certainly address specific market segment. Initially it will approach large organizations who directly import chemicals for own consumption. Distributors are also been engaged for marketing these basic chemicals.

\section{Market size and growth rate}

Main participants/competitors of this market are import. To control import, initially basic chemicals product have be positioned in such a way that the quality will be as good as imported items and pricing will be slightly low. Once the companies will be used to enjoy facility of local supply they will slowly migrate to the local products. At that time pricing of local produced chemicals will be slightly higher than imported goods.

\section{Competitive Advantage}

Quick delivery of good quality local product of consistent standard will be the essence of our marketing. End user industries at this stage are import dependent. If they want to maintain quality of their work they cannot purchase chemicals from local market. In most cases quality conscious end users directly import chemicals blocking big fund. Basic Chemicals production plants have substantial contribution to these customers.

\section{Industry participant and product positioning}

Qualified Chemical Engineers and Chemists will have to recruit for marketing basic chemicals products. They will visit door to door of prospective customers to educate them to use local product. Side by side direct sale company will have distributor network to handle the products.

Textile industries, pulp and paper industry, pharmaceuticals, Soap industry and some chemical industries will be our main focus. Executing with chemical background and marketing neck will be utilized to educate them the customer. We will arrange seminars and symposium to inform the prospective customers about our presence. Above all we will print leaflets, pamphlets spelling out the specialty of our products. 
Bulk consumer of our products will be an industrial customer. They will use our products as raw materials. As they will use the products in volume we will put special care to enter into that market. We will not go for newspaper advertisement for attracting industrial customer because we feel it will not be very useful.

But sodium hypochlorite $(\mathrm{NaOCl})$ and Activated bleaching earth (ABE) will have a consumer market segment. We will have billboard and we will go for media advertisement to enter into consumer market. It will increase visibility of our brand. After all visibility is business.

\section{Availability of basic chemicals products}

It is essential to put high concentration to ensure the easy availability of the products to the prospective customer. Regional warehouse to be made all over the country to ensure easy availability of the product. It will be arranged to deliver the domestic products to super markets \& departmental stores through our distributor network.

\section{Challenges of Basic Chemicals Industries and its product:}

1. For Chlor-Alkali plant, more consumption of $\mathrm{Cl}_{2}$ is required to run the plant at design capacity. PVC plant is required to consume excess $\mathrm{Cl} 2$ from Chlor-alkali Plant.

2. More water treatment plant to be made by WASA at the different area of the country to increase liquid $\mathrm{Cl}_{2}$ consumption.

3. $\mathrm{Cl}_{2}$ can be used for de-coloring of dyeing waste colored water. In that case Liquid $\mathrm{Cl}_{2}$ consumption from ChlorAlkali Plant will be increased. The treatment of wastewater with chlorine gas is a proven process and this was discarded primarily for high cost of chlorine gas. The situation is different in Bangladesh and the cost of chlorine here favors the adoption of this proven process. This process provides an opportunity for both the industry and DOE to perform in a Win-Win situation. Instead of being awkwardly insincere and dishonest with our mission to serve the nation and its people by ensuring a clean environment, both the parties should strive hard to operate ETPs for complying with ECR-97 requirements. The wastewater treatment with chlorine gas can make all the difference by doing something positive rather than being smart by doing nothing purposefully. Operating experiences reveal that the cost of chlorine consumed is very low compared to the chemicals and aids used previously. These industries are now eager and committed to operate ETPs. Satisfactory operation of ETPs would require monitoring of $\mathrm{pH}$, TDS, color, odor and free chlorine so that the right dose of chlorination is employed. In some ETPs adjustment of $\mathrm{pH}$ before chlorination and after treatment may be required.

4. $\mathrm{FeCl}_{3}$ and PAC (Poly Aluminium Chloride) industry to be made to increase liquid Chlorine consumption.

5. Basic chemicals import should be stooped so that local production slow consumed chemicals like $\mathrm{HCl}, \mathrm{SBP}$, CPW plant will be running well.
6. We have to make central ETP at different industrial area and $\mathrm{HCl}$ consumption should be increase to balance $\mathrm{Cl}_{2}$ from Chlor-Alkali Plant.

7. Regeneration of resins of DM plant to be done by $\mathrm{HCl}$ instead of $\mathrm{H}_{2} \mathrm{SO}_{4}$.

8. Now Basic Chemicals plants are suspending due to natural gas permission from the government

\section{Conclusion}

The first Chlor-Alkali Plant has commenced its commercial production from 2002 in the private sector and the products have acquired a strong foothold in the market within a very short time. The first Hydrogen Peroxide plant is in full operation from early 2005 and the peroxide has graced the market with huge success. ASM Chemical Industries Ltd., an integrated Chlor-Alkali \& Hydrogen Peroxide plant was established in 2006 and was commissioned in 2008. The feasibility of the project has been conducted and analyzed from the viewpoint of marketing, technical, financial, management, and economic aspects, and was found to be a worthwhile and desirable investment opportunity. The projected financial results and the profitability estimated based on the assumptions explained in this report indicates that this project would successfully service a niche market that has not yet been explored fully and hence it is a very lucrative proposition. The versatile demand for Peroxide, Caustic and its other bi-products are currently met through imports and are sold for premium prices. Moreover, the huge prospect in the textile sector is also going to increase the demand for Caustic Soda and $\mathrm{H}_{2} \mathrm{O}_{2}$ in the near future. These scenarios, coupled with the overall industrialization trend in Bangladesh, present us with a unique opportunity for backward integration and service a niche but secured market, and gain huge profit while adding the country's GDP. 